\title{
Design workshops to develop a digital educator's tool
}

\author{
Susanne Kjällander
}

\section{Introduction}

This chapter will focus on Designs for Learning (Selander, 2008, 2017; Selander \& Kress, 2017) by means of analyzing the building of digital tools for use in preschools. It will also discuss what it means to do research with preschool teachers in an intervention project where the research questions were asked by the educators themselves; something embraced by the notion of designs in learning (Selander \& Kress, 2017; see also Chapter 2 by Lindstrand \& Selander in this volume). Empirical material from the project DigiTaktik-Digital Tools as a Method for Learning and Formative Feedback in the Context of Number Sense and Early Math Skills will illustrate how educators and researchers in collaboration design for and in learning while developing a digital tool. In this chapter, illustrative empirical examples from the design process will be followed by interview quotes from the workshops. The chapter will conclude by highlighting the importance of collaboration across disciplines as well as professions.

\section{Aim and research question}

This project was preceded by an existing collaboration between preschools and Stockholm University. In earlier research projects where the mathematics learning game Magical Garden ${ }^{1}$ had been used, educators indicated that they were concerned by their lack of insight into children's mathematical knowledge. They asked for a device to visualize children's design in learning which led to a new research project arising from the needs expressed by the educators.

During two years of collaborative work, the teachers and the researchers developed an educator's tool that could be used to support children's individual learning in the context of group-oriented practice. The theoretical perspective Designs for Learning (Selander, 2008; Selander \& Kress, 2017; also see Chapters 1 (Selander) \& 2 (Lindstrand \& Selander)) was used, and this chapter deals with methodological issues concerning how a workshop series could collect and analyze empirical material. It will also discuss how teachers and researchers, within the frame of a workshop series, can develop and design a 
new, digital, and multimodal, educator's tool. A central question in this project and chapter is:

- How was the model Learning Design Sequence (LDS) used as a theoretical perspective for analyzing a two-year workshop series, with the aim to develop a functional educator's tool, in order to help preschool teachers to intervene in children's early mathematics learning?

The findings of the research question were developed through analysis of data from a series of workshops. The design was planned and executed in collaboration with two preschool teachers (who are part of the project group) and five researchers from interdisciplinary fields: didactic science, cognitive science, psychology, and neuroscience. The tool was designed together with approximately 30 educators. This chapter shows the use of LDS as a resource in designing and analyzing the workshops in relation to the educator's tool.

\section{Digital tools to support children's learning and teacher's professions}

Magical Garden (Gulz et al., 2020b; Husain et al., 2015) is the name of a research based digital mathematics learning game that is used and further developed within the project DigiTaktik. The game use is adaptive in the sense that it continuously adapts to the individual child - by means of a weighted historical success rate, the number of times a particular task has been practiced, and how fast the child advances through the game. The game is based on the pedagogical principle of learning-by-teaching, with the child taking on the instructor's role and helping a digital tutee-a teachable agent-solve tasks of progressive difficulty (Biswas et al., 2001).

Earlier research (Moreno-Ger et al., 2008) suggests that it is not especially hard to create a digital tool for educational purposes. What is hard, according to the authors, is making sure that the digital tool, app, or game is both educational and entertaining. This means that the testing process, evaluation, and re-design are expensive and result in many designs or developments being rejected or even failing, sometimes almost immediately.

However, the subsequent development and use of Artificial Intelligence (AI) offers new possibilities. AI could, for example, make a difference in the development of digital resources for education, since the metadata can create programs where teachers can see what children know and what they are struggling with. In this way, the subject content can be individualized, making it possible for children to learn at their own pace. When preschool children's' groups are large, it is hard for the individual preschool teacher in their daily work to follow each child's individual mathematics learning (Kjällander, 2019). 


\section{Workshop as a research method}

In a literature review, Ørngreen and Levinsen (2017) characterize the workshop format, highlighting some common features in the massive body of research workshops. They are arranged events with limited duration, and the participants have things in common and often work in the same professional field. Workshops have shared agendas, such as participatory design, and they are often conducted by people with experience; they promote genuine participation, often in small participant groups where they allow personal attention and where everyone can be heard. Active participation is required and participants may influence the workshop's direction. During the workshop it is expected that the participants practice the relevant techniques, skills, and situations. These findings have guided our workshop series in the project DigiTaktik. Much of what has been discussed above is embraced by our "workshop model." Calkins and Tolan (2010) indicate that all workshops should be designed to guide participation and engagement, which are considered dynamically linked to learning (also see Chapter 9 by Insulander \& Svärdemo Åberg in this volume).

Ciampa (2016), who has planned, designed, analyzed, and evaluated workshops in a research project, concluded that: "Teachers cannot just read about Web-based and digital resources; they must begin exploring these resources for themselves" (p. 305). In launching the Technology Professional Development Workshop, the researchers concerned highlighted the workshop as a method where the professional learning would be responsive to the teachers' identified needs, as a result of a "preworkshop needs assessment" (p. 296) that the teachers completed. During the workshops, individualization and feedback were crucial: "We also need to visualize new ways to take advantage of the Web-based and digital resources that are available to disciplinary literacy educators that allow for individualization and immediate and personalized feedback" (p. 305). This chapter takes up that challenge.

Workshops can, according to Ørngreen and Levinsen (2017), be divided into three different categories: (a) workshops as means, (b) workshops as practice, and (c) workshops as research methodology. The category "Workshops as means" came to be the category most relevant to this chapter. It is also a category with much published literature, and is explained as authentic workshops having the aim of achieving specific goals. These goals can have to do with outcomes that result from participating in the workshop, such as teachers' transformed practices, new competencies, new ideas, or even new knowledge. In our workshop series we aimed to achieve all such outcomes.

\section{Designs for learning and the learning design sequences}

To design a collaborative process of the development of the digital educator's tool in a workshop series, a theoretical model, Learning Designs Sequence (LDS) (see Figure 6.1), was adopted and used for analysis. 


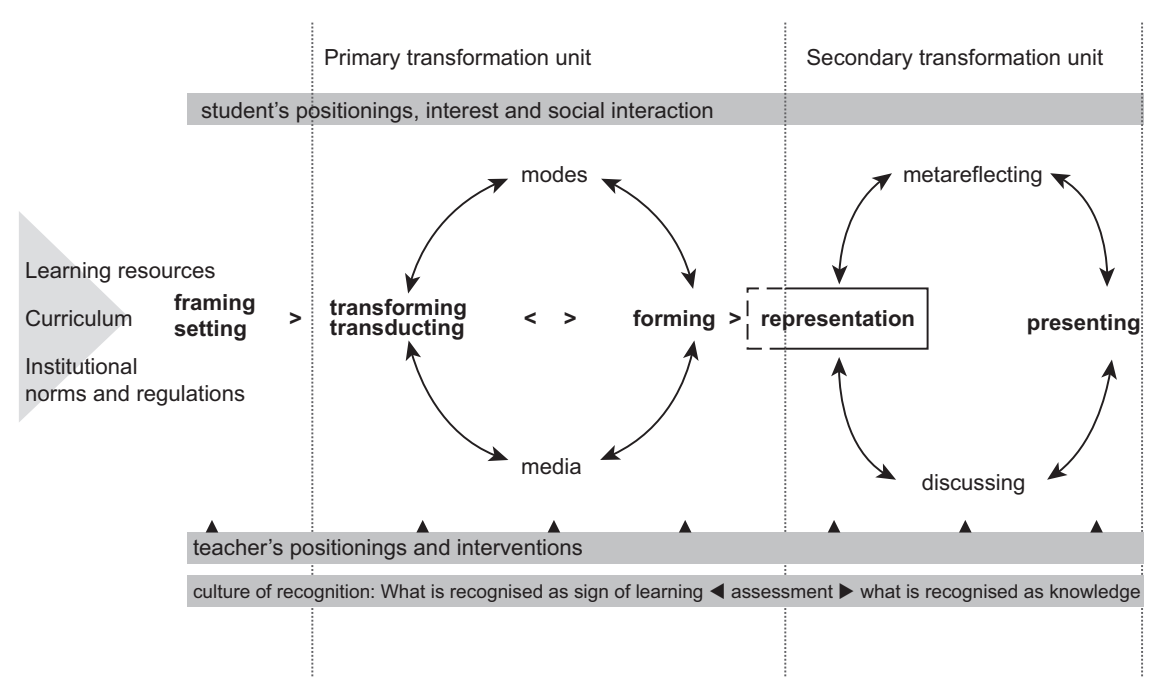

Figure 6.I The Learning Design Sequence.

Source: (a revised version of the model in Selander, 2008, p. 17; Revision by Selander and Boistrup, designed by Routledge)

The model in Figure 6.1 can be used to design and analyze teaching in a classroom (see also Chapter 5 by Boistrup \& Hällback in this volume), learning at a museum or, as in this chapter, the design and analysis of a workshop series. Different parts of the model can be important according to which questions are central for each particular project. In this chapter, the following categories were central: the setting (which is the research group's planning), the transforming (which is the educators' and researchers' process of creating the educator's tool), the forming (which is the formation of the tool), and the representation (which is the way the participants' understanding has been reflected in the design).

In the communication between researchers, educators, and resources, meaning is made by different modes such as speech, gestures, mimic, texts, and body position, as well as through colour, photo, symbols, sound effects, music, layout, and moving image (Kress \& van Leeuwen, 2001). The LDS model is used here to establish an environment where educators and researchers, working in cooperation, can develop and analyze an educators' tool. Different modes are of different importance in different situations (Kress et al., 2001), and the workshop participants choose the media (e.g., paper, pens, cello tape) and the modes that seem to fit the situation best. Their choices are illustrated in this workshop series where the tool is designed multimodally in a transformative process (Selander, 2009, p. 21).

The workshop series took place over slightly more than two years. The project can be read as a series of three sequences, initiated in the setting, and 
then transformed, and formed anew. The workshop series can also be understood as one whole sequence, with an introduction (setting), work (transforming and forming), and a presentation of the work (representation). The educator's tool was also to be used to strengthen children's individual early mathematics learning in the context of group-oriented practices by inviting educators to intervene in a child's learning processes, thereby gaining a view of their progress in the game-perhaps seeing that they seem to struggle at some point and are not moving forward - and on the basis of this having the possibility to gather a small group of children to play a related physical game to practice what seems difficult for the child, for example.

\section{Methodological and ethical considerations}

All empirical material was created within the frames of the multidisciplinary and mixed methods research project DigiTaktik-Digital Tools as a Method for Learning and Formative Feedback in the Context of Number Sense and Early Math Skills. The research project strictly followed the Swedish Research Council's ethical guidelines for research on human persons and was granted clearance by the ethics committee of the Karolinska Institute. Special attention was paid to participants' body language, including gestures and posture.

In this section, I will present illustrative empirical examples from the design process, complemented by educators' and researchers' quotes from the praxisbased research workshops. The ethical considerations in this project were very challenging since the Covid-19 pandemic broke out in the middle of it. We struggled to make the right ethical decisions, but it happened that the most ethical approach was not always the safest.

\section{Design of the workshop series}

The workshop series was designed and analyzed within the theoretical framework of Designs for Learning (DFL) (Selander, 2008), using the theoretical concepts (shown in italics) from the model Learning Design Sequence-[LDS] (Selander, 2008). According to Ørngreen and Levinsen (2017), workshops can be designed as both singular and successive events. In this project, five multimodal (Kress, 2010; Selander \& Kress, 2017; van Leeuwen, 2005) workshops were designed, executed, documented, and analyzed in collaborative processes of social interaction between the field and the academy. The number of participants during the five workshops ranged from 9 to 23 , and caregivers, preschool teachers, preschool headmasters/mistresses, teachers, and researchers all took part. Long before the first workshop, an informational letter was sent to all teachers who had been working with the game Magical Garden in an earlier research project and to all teachers who are now part of the project DigiTaktik. At the end of 2018 the workshop series was initiated with an invitation to a day of presentations, workshops, discussions, and aesthetic work, with food and 
coffee-breaks. The following events were included in the workshop series over two years, a whole LDS, and divided into different stages of the LDS model:

x Pre-workshop (2018) (setting).

1 WS1 (December 2018) Paper prototype informed by the game designers and formed by groups of 20 educators with paper, pens, scissors, and glue (setting).

2 WS2 (June 2019) Digital prototype1 presented to about 20 participants. The prototype was tested and revised while instruction videos were recorded, texts were written, and images designed, and a lecture about digital tools in preschool was held (transforming ).

3 WS3 (November 2019) Digital prototype2 tested and modified in cooperation with approximately 20 educators (transforming ).

4 WS4 (April 2020) Digital prototype3 tested and modified with a few participants online via Zoom due to the Covid-19 pandemic; therefore, two more WS4s were executed at two different preschools (forming ).

5 WS5 (September 2020) the Digital prototype4 of the tool was presented to about 15 participants and tested and modified just before the research pilot study (representation).

Magnus Haake designed and lead the whole workshop series, supported by the DigiTaktik research team. Also, all workshops can be understood as having completed one LDS each. Some of the researchers ${ }^{2}$ had extensive experience of working with workshops as a research method, while others were more used to video ethnography. ${ }^{3}$ Thus, a two-folded method was used where field notes and photos were taken and where some parts were video documented.

Ørngreen and Levinsen (2017, p. 79) also underline that "In a workshop, issues can be presented, experimented with, played out, and discussed. Thus, when workshops are applied as part of a research design, the researcher opts for an immersive and collaborative environment where meaning is negotiated." The research team was well prepared to design for genuine cooperation, not least since we were financed by an authority for praxis-based research. Based on Selander (2017), we were keen to design the workshop so that educators would "be able to process, transform, and use information as well as develop [an] action repertoire and assessment abilities—and thus be able to participate in a meaningful way in a knowledge domain" (p. 37, my translation).

\section{Design of the workshops-analysis and results}

The series of praxis-based research workshops was planned in close relation to and cooperation between (a) two stakeholders (i.e., two preschool teachers who are part of the project group) and (b) five researchers from interdisciplinary fields: didactic science, cognitive science, psychology, and neuroscience. In the following, the different workshops will be presented in chronological order, 
with empirical excerpts. They will be briefly analyzed using design theoretical notions and conclude with a list of functions implemented in the educator's tool prototype. For transparency, the first workshop [WS1] will be illustrated and explained, whereas WSs $2-5$ will be presentenced in less detail.

\section{Pre-workshops-autumn 2018}

In the LDS model the pre-WS can be placed before the setting (as shown in Figure 6.2), where environmental issues such as resources, curriculum, and norms are important.

The LDS model shows that the setting has a prominent impact on the whole transformative process in the two transformation units. Earlier research indicates that it is important to have a "pre-workshop" (Ciampa, 2016) where the teachers' identified needs are highlighted and worked out as a starting point. Before the first workshop we had several pre-workshops within the research team with the two preschool teachers, where relevant information was given about what was possible to expect from educators' experiences, attitudes and knowledge of digital resources, digital games and possibly also other digital teacher's tools. The two stakeholders then had meetings with educators to identify their experience, expectations, and needs (Ciampa, 2016). Half of the invited educators had previously been part of one of our earlier research projects in the same area, and the other half were working in the same area as the two stakeholders who are part of the research team. From the very first meeting we were thus a cohesive group with things in common, working in the same field, and with shared agendas (Ørngreen \& Levinsen, 2017).

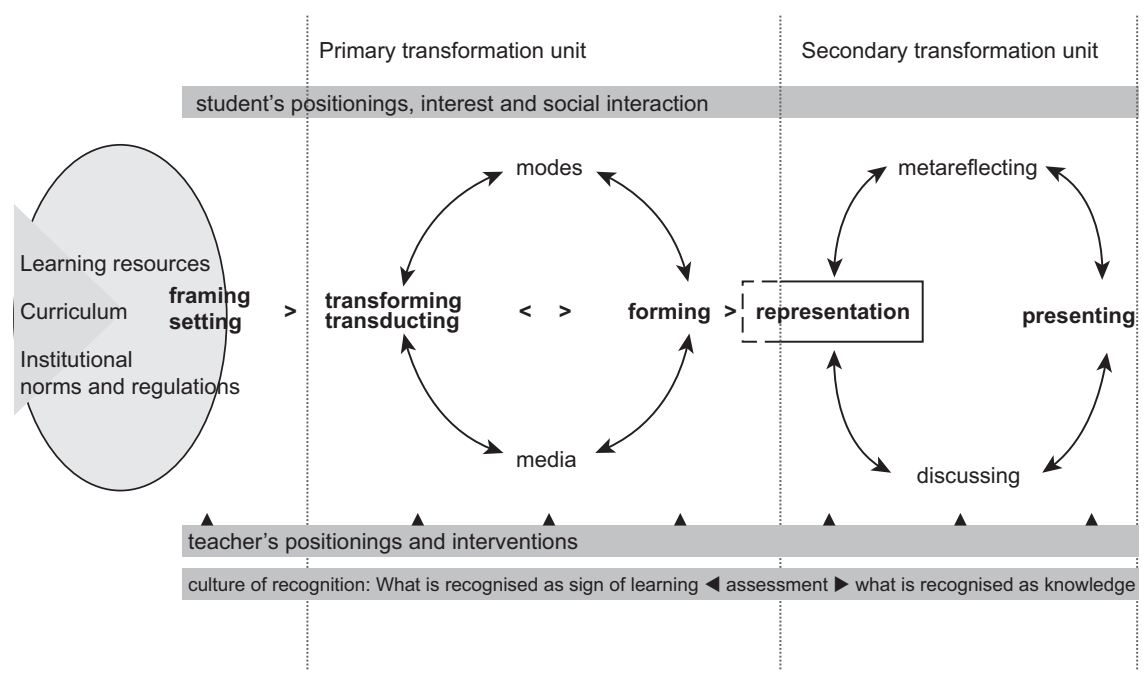

Figure 6.2 The LDS setting. 


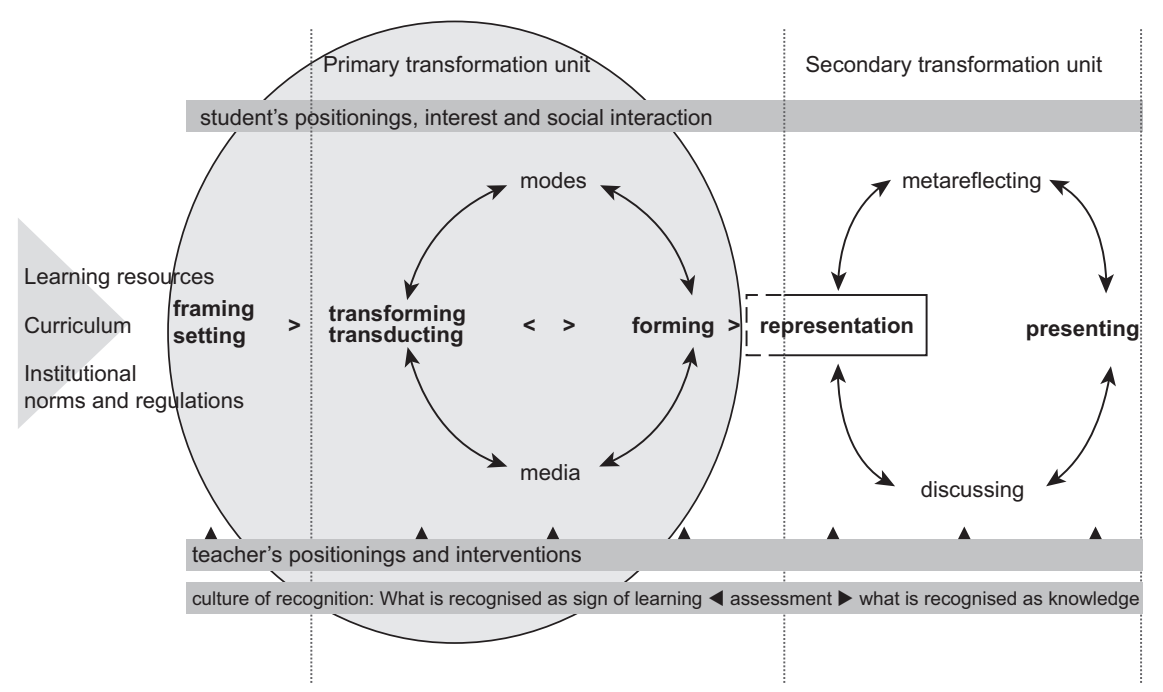

Figure 6.3 The LDS primary transformation unit.

\section{WSI-empirical example}

In the LDS, comprising all of the workshops during the 2 years, WS1 (201812-03) can be placed in the setting section, where environmental issues such as resources, curriculum, and norms are important, along with the educators, as well as in in the primary transformation unit (see Figure 6.3).

Our research project was introduced by the municipality school operations manager via newsletters, platforms, and workplace meetings. For some educators who had taken part in an earlier research project with some of the researchers, the following letter was not unexpected.

\section{WSI The setting}

An invitation letter (Figure 6.4) was sent to possible workshop members. In the setting, the norms, expectations, preschool mathematics curriculum, project problem, aim and research questions, the game Magical Garden, and finally the resources (modes and media) were thoroughly introduced. Informed consent forms were handed out and signed by all educators.

\section{WSI The primary transformation unit}

This first workshop (WS1) was arranged with a strict structure and designed to comprise the whole Learning Design Sequence in six steps, out of which the first five were part of the first transformation unit. 
Hi! You receive this invitation for being a xx teacher in the project $x x$ or since you will participate in the research project DigiTaktik. Stockholm and Lund University received funding from the Swedish Institute of Educational Research for the new research project DigiTaktik on mathematics in preschool. In the first step of the project we would like to invite you to participate in a workshop where you can share your experiences about working with or supervising work with Magical Garden. Together we will have a workshop on how a digital pedagogic tool in mathematics could be designed. The project group will organize the workshop led by xx. This workshop is the first in a number of occasions where some are about developing the pedagogic tool and others about in-service training by us and other researchers talking about, among other things, digitization in preschool.

Where? $x x$

When? Dec 3rd, 15-19

How? Bring your own devise if you have one.

We offer a simpler meal.

RSVP: To $x x$ no later than Oct $31^{\text {st }}$

More info: You will get more information when you register or if you contact project leader $x x$

A warm welcome! wishes from $x x$

Figure 6.4 Invitation letter to educators introducing the setting and the aim of the project.

Source: (Photographed and owned by Susanne Kjällander)

In this first part of the LDS, the educators and researchers were supposed to transform and form an idea and a physical prototype with different modes (e.g., text, images, symbols, colours) and media (physical resources such as scissors, paper, pencils, and also an intended website, a platform, a social media group, an app, etc.).

The workshop was introduced by an experienced researcher giving instructions on a few points, describing the modes and media that could be used (see Figure 6.5). The other researchers paid extra attention to the interests as expressed by the educators and the social interaction going on among them. The researchers intervened at the beginning of the primary transformation unit by introducing the assignment and supporting the educators' social interaction.

1 Welcome, introduction, division into groups (approximately four persons per group).

2 Brief walk through/repetition of Magical Garden + introduction to what is behind the game in Magical Garden (e.g., what data is "logged" and what information can be accessed).

3 Present a ready-made booklet about Magical Garden. This material could/ should be used during the design process.

4 Discussion (see below) in groups for 10-15 minutes.

5 The discussions are also a "warm up" for the design process in the next step. A set of questions was presented on the whiteboard: What was it like working with Magical Garden? How can you use this type of game in a better way? What does the preschool teacher need in order to use Magical Garden in the best way? (e.g., a question bank, tutorials, digital platform, teacher tutorial, educational material, other teaching tools?) Do you need (or want) knowledge of mathematics or knowledge of how children learn 


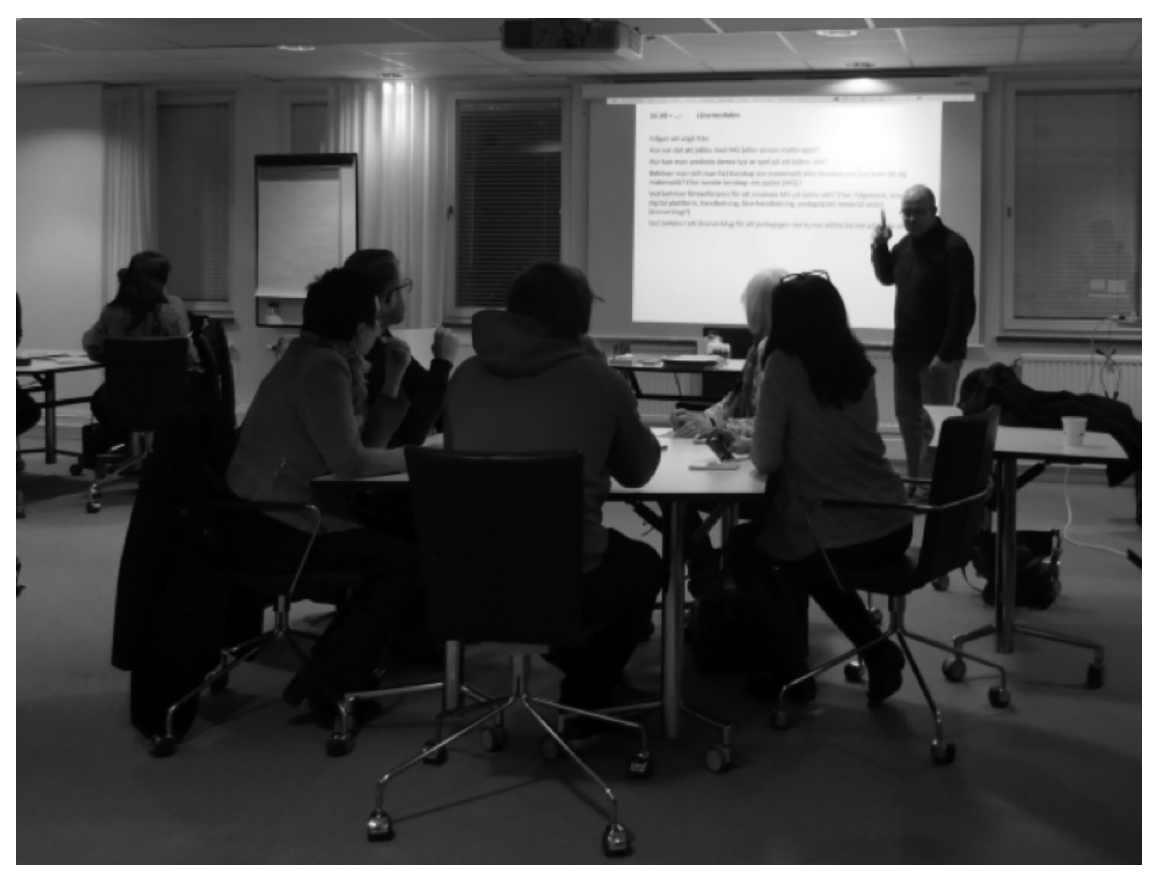

Figure 6.5 Photo:The interests and social interaction and the researcher's intervention at the beginning of the first transformation unit.

Source: (Photographed and owned by Susanne Kjällander)

mathematics? Or maybe knowledge of the game Magical Garden? This part of the transformative work ended with a gathering of the big group in a joint summary and review process.

In this gathering, questions and discussions took place during the first part of the primary transformation unit where the educators were engaged in transforming. In Excerpt 6.1, a few selected quotes from the educators are displayed:

\section{Excerpt 6.I This excerpt illustrates a discussion when no one knows what kind of tool will be developed.}

- What shall we call what is to be developed? Learning Tools, Teacher's Guide, Teacher Module? 
- It is important that educators have the early mathematics understanding, so that they can understand the children's learning processes. Today, some educators in Swedish preschool are lacking basic knowledge. How could the learning tool develop the educator's own approach to math?

- To go back and see what the children need to work more with, would be a good idea. Can you see the curves, the progression, in the game? The children who have come a very long way: how do we challenge them?

- The teaching tool can deal with both digital and analogue parts.

In this excerpt, ideas about the educators making the tool an educative one for themselves are initiated, and the curriculum-based idea of using a digital tool along with physical tools is introduced. The work of the design process aiming at producing proposals for an educator's tool took place during approximately 2.5 hours: a fast but powerful design process. The assignment was to develop a so-called Lo Fi prototype for an educator module. The Lo Fi prototype can be described as a visual representation of a digital product that will have little resemblance in appearance, but not in function, to the final digital design.

A prototype can take different forms, and in this case it was most likely to take a physical form since we handed out physical materials. On the other hand, since "bring your own device" was mentioned in the invitation, many digital tablets were laying on the tables as well and used in some groups. The workflow designed by the researchers and presented to the educators during the first part of the primary transformation unit had the aim of engaging educators in the process of transforming by following instructions in the steps (a)-(d) (see Excerpt 6.2).

\section{Excerpt 6.2 Instructions given to the educators in the primary transformation unit.}

a) Structured brainstorming. Generate suggestions for features and services in an educator module. Use the questions: "What did you miss in Magical Garden as an educator?", "What kind of educator support would you have wanted in Magical Garden?" Structured brainstorming involves loading pieces of paper with suggestions into a common pile; a minimum five pieces 
per educator, but the goal is to accumulate as many pieces (suggestions) as possible. During the so-called structured brainstorming, you should not talk to each other-and it is especially forbidden to comment on each other's suggestions;

b) Function analysis. Review the suggestions and sort them (and now you get to talk) based on the I) necessary, 2) desirable or 3) excluded/removed functions and services. The proposals sorted under "a) necessary" shall be commented on/clarified;

c) Prototyping: Sketch (visual) interfaces with paper, scissors and coloured pencils —or use digital prototyping support;

d) Presentation \& walkthrough: Present your thoughts to the rest of the educators and researchers in the workshop.

The instructions in this excerpt were structured since the researchers were keen to keep the educators' interest focused on the tool. In the following, a selection of the educators' questions and discussions during the second part of the primary transformation unit is presented. The educators were engaged in forming and said:

\section{Excerpt 6.3 Educators' ideas about the educator's tool have developed and are in this part of the LDS more concrete with innovative suggestions on design, content, and functions.}

- Do you have to work with analogue first and digitally then? Can you go directly on the digital?

A discussion takes place about a well-known teaching resource, "Favourite mathematics," which is a program with a teacher's guide. It is concrete material in a digital form. The educators want the app to clearly visualize the mathematics areas in focus. There are also some ideas on tool content such as: subject headings and instructional film/suggestions for analogue activities.

The educators suggest an activity fill-in-box about who has worked today, on which page, as well as attendance list, statistics and progression. They would like the tool to enable them to log in and choose an alias/picture of each child and click, for example, "active" or "not active." They want to identify inactive 
children and identify areas where children get stuck, as suggested, with notifications/alerts to the educator. They ask for a forum to share experiences with others and a tool with instructional videos rather than text-they want inspirational educational films for both children and adults. They highlight that the learning tool must be suitable for educators with different skills, both trained and untrained.

In the primary transformation unit, as seen in this excerpt, a design process was accomplished and visualized in the educator's exploration, learning, and transformative multimodal work that took place in different modes and media such as spoken ideas, written notes, paper models, and symbols. By the end of the primary transformation unit the educators formed the very first prototypes for the educator's tool. Discussions were made both in a large group and in smaller constellations (see Figure 6.6).

\section{WSI Secondary transformation unit}

The last step in the design process of WS1 took place in the secondary transformation unit: Collection and walkthrough of all groups' multimodal representations. In this part, three different kinds of physical representations were formed and designed out of paper, pens, and cello tape, but referring to a digital tool: the very first prototypes of the educator's tool, which can be seen in Figure 6.7.

Each group of five educators presented their prototype, as seen in Figure 6.7. A researcher guided the metareflection and discussion in the whole WS group. Since all the prototypes must be transformed into one digital prototype, common

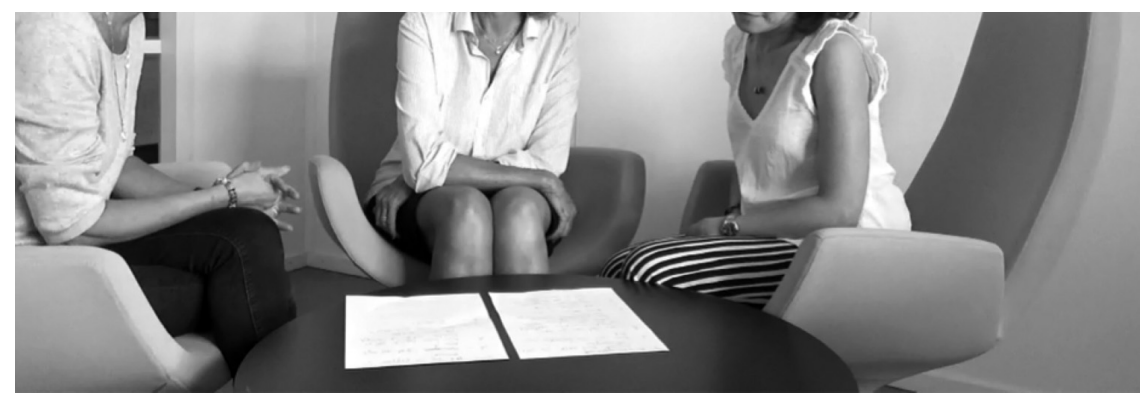

Figure 6.6 The oral brainstorm in one group is transducted to written text on paper.

Source: (Photographed and owned by Susanne Kjällander) 


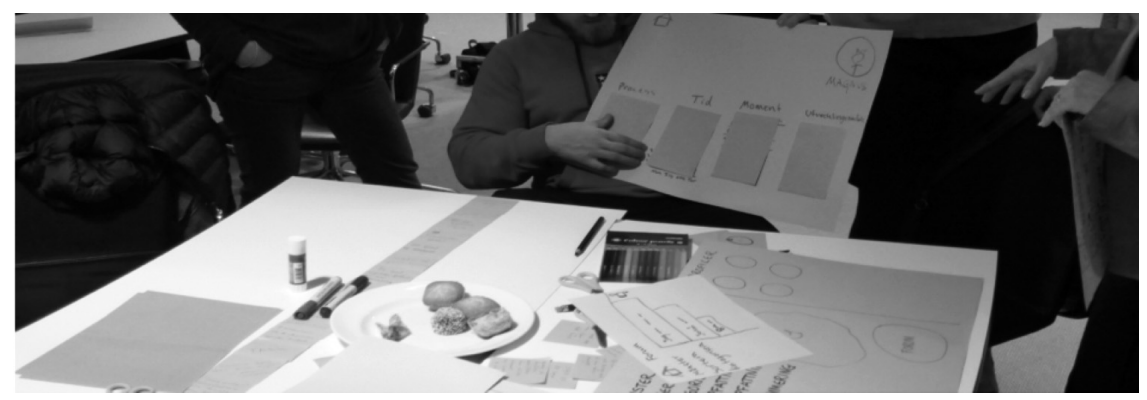

Figure 6.7 The very first prototype of the educator's tool formed by the educators in WSI. Source: (Photographed and owned by Susanne Kjällander)

features were gathered and displayed by a researcher on the whiteboard. Below are examples of quotes made by the educators during the secondary transformation unit:

\section{Excerpt 6.4 Discussions in this part of the LDS focus on the educators' everyday teaching at the preschool. The subject of mathematics is also discussed, what is embraced, and how it should be inclusive as well as physical.}

- Mathematical patterns are important - how can they be visualized and trained? Can the tool ease ... support ... encourage talking mathematics with children? Physical exercises should be included, for example, brain training, since the human encounter and the analogue material are important.

- $\quad$ Forum for collegial sharing and learning (both for educators and programmers). The tool must be able to enter and use with only a few minutes of preparation time. It may be important not only to do extra tasks with the children who really need to, but not to single out any child.

- Is there a risk with too much information or too much documentation?

In this excerpt, educators express more elaborated suggestions since they had time to metareflect on the possible content and functions of the tool, and since their quotes come from a discussion in the whole group, when an utterance can be understood as a motivated sign in a presenting mode. 


\section{WSI Analysis of the primary and the secondary transformation unit}

In the first WS we strove to design an accommodating social interaction where all educators could participate (regardless of digital competence) and we encouraged their multimodal transforming and forming processes. Our interventions in the discussions at all times implied that everything was possible and that their representations did not have to be realistic or feasible at this stage. This approach — or didactic design — was appreciated as an affordance by the educators who came up with ideas of children's aliases, and the idea that the tool should include physical matters such as "Brain train" (Neville et al., 2013). In all groups transduction (Kress, 2010; Newfield, 2014) took place where a brainstorm, with modes such as words and gestures, was transducted to the mode of written text, which was again transducted into the mode of colour, text, and symbols on a poster.

\section{Examples of results from WSI implemented in the prototype}

Some crucial parts of the tool were invented during WS1 and later incorporated into the final tool:

- The importance of using the same notions for learning, early mathematics, preschool didactics, digital resources, and the teacher's assignment, preferably with references to the National curriculum (National Agency for Education, 2018).

- Early mathematics - the realization that early mathematics must be learned, and does not develop automatically, must be presented in the tool

- The tool must be simple to navigate and there should be different tabs for different content (e.g., mathematical games, Brain Train, and educational films)

- Both physical and digital resources should be used together, according to the National curriculum for Swedish preschool. This standpoint is incorporated in the extended digital interface, and in the classroom with physical exercises, games with blocks, bean bags, and other physical objects connected to the mathematical content in the educator's tool.

- Visibility of children's progression within the game

\section{WS2-empirical example}

In the whole LDS, WS2 (June 18, 2019) can be placed in the primary transformation unit where transforming occurs and the educator's role is important.

\section{WS2 setting}

The setting for WS2 was explained as follows in the invitation: "With support in the material from Workshop1, a first prototype of a digital teacher's tool in mathematics, has now been created." The learning resources had, at this point, 
already been transformed from the physical to the digital (by programmers at Lund University), and the institutional norms (such as the aim of the research project and the invitation) indicated that the workshop would focus on the digital prototype.

\section{WS2 primary transformation unit}

One of the researchers went through the game on the projector. The first prototypes on the educator's tool were presented: The different tabs, and what is supposed to be visible under each tab, were displayed. One of the tabs was explored together in the group and a recorded film clip was viewed and discussed collaboratively. Participants all agreed that they wanted all available information: the game, the films, and the information to be displayed on the same page/platform/resource. WS2 was organized in three groups, but educators were allowed to try all activities and to go between the groups where they were supposed to transform and form their preferences by: (a) writing texts; (b) drawing models; and (c) recording film clips. The researchers walked through the groups and intervened by supporting, asking questions, answering questions, handing out material, and assisting with cameras and other techniques. In all three groups a common theme arose: the importance of a common language between the tool and everyday life in preschool. That was also the case for the discussion about what the tool should be called, as presented below in Excerpt 6.5:

\section{Excerpt 6.5 Suggestions on what the tool can be called. \\ - "Platform" \\ - "Module" \\ - "Teacher's guide" \\ - "Teacher's tool" \\ - "Educator's tool" \\ Most participants vote for "Teacher's tool”.}

There are many different views of what the tool could be called, as seen in Excerpt 6.5, and over many months it was called "teacher's tool" until it was evident that such a word would exclude professions other than educated preschool teachers. 


\section{WS2 secondary transformation unit}

During the last part of WS2, all groups presented the products of their work which were much appreciated by the audience. Following this, a metareflection was guided by the researchers and different suggestions were assessed on their feasibility for designing into the tool. Some important discussions and decisions took place about both children's early mathematics and educators' own mathematical knowledge.

\section{WS2 analysis of the primary and secondary transformation unit}

The didactic design in WS2 was to engage the educators in the physical production of multimodal parts of the tool. It is a simple task to come up with amazing ideas and visions during a WS, but a difficult business to transform them into a representation. The educators were productive during the WS and transformed their ideas into an assembly of texts, films, and models. Possibly the multimodal assignment with a focus on image was appreciated as a prompt (van Leeuwen, 2005) to visualize children's learning in the tool. When they were viewing the prototype in the WS setting, no-one reacted to the words used, but when they were engaged in transforming and producing (e.g., recording a staged interview with each other about early mathematics) they used the same language as in the curricular texts they were familiar with. This was discussed with a lot of interest and engagement, and the researchers realized how important it was for the tool to be trusted by educators. This is related to the discussion that the tool must be called something that would be deemed trustworthy. It must appeal to everyone, yet not exclude anyone. In preschool, people with different educational backgrounds work together, and almost no-one is a teacher, still they chose the name "teachers' tool." Later, after the metareflective round, they reconsidered and chose "educator's tool" ("pedagogverktyg") to include everyone. Since the Swedish expression (pedagogical tool) would give the wrong connotation in English, in this chapter we call it "educator's tool."

\section{Examples of results from WS2 implemented in the prototype}

The game Magical Garden was discussed a lot during WS2. The different levels/worlds/tracks (such as the "Bumblebee Humfrid," "The Bird Rescue," and "The Crane," as well as a set of additional games such as "The Birthday Party" and "The Labyrinth") were the main focus. The following are a few examples of results from WS2 that were implemented in the prototype:

- Notions from the national curriculum, such as "room" and "form" instead of "spatial perception"

- The possibility of making the game cooperative by means of the tool, so that children can play one or two levels/worlds/tracks together or show each other the plants that are growing in their Magical Garden 
- The importance of visibility of children's mathematics knowledge in, for example, diagrams to visualize if the child is practising subtraction in the number range of $0-4$

- The importance of a display of all 9 levels/worlds/tracks and an indicator of where the child is playing currently

- Aims with the different levels/worlds/tracks must be pronounced so that the educator will know that "The Bumblebee Humfrid" is mainly training position while "The Crane" is mainly training number sense.

\section{WS3-empirical example}

WS3 (November 14, 2019) can be placed in the LDS model's primary transformation unit, where the educators are in the transformative process.

\section{WS3 setting}

In the setting of WS3 the prototype and its modes and media were set as "homework" for educators to prepare beforehand. A set of questions was sent out beforehand:

1 Think through what kind of information about children's learning you would like the system to give you. Be concrete and specific. Be prepared to explain how you could know that about a child.

2 Consider situations when you would like to use the educator's tool to find out more information about one or more children's learning. Is it inside or outside a children's group, as part of another activity, or as a separate activity in itself? Be concrete and specific. Be prepared to explain what would be required of the system for it to work in that situation.

This was a new didactic design - the two earlier WSs had not asked for any preparation, meaning that the setting started at the WS, but in this case the setting was initiated prior to the WS, at home.

\section{WS3 primary transformation unit}

In the primary transformation unit a preliminary version of the developed educator's tool was displayed. The tool's affordances (Gibson, 1979, Kress, 2010, see also Chapter 3 by Lindstrand, this volume), such as links to in-depth text for the user to choose, were presented. For example, the automatic linear presentation of the game and the tool with images and narrators caught the educators' interests. Small group discussions were focused on what else could be solved by the game. A masters student presented her prototype of a "follow-up tool" as invented in WS2. The educators showed great interest in this aspect of the tool and came up with many suggestions for development. Below, in Excerpt 6.6, are examples of questions and discussions by the educators during the primary transformation unit: 


\section{Excerpt 6.6 A summary of questions and discussions in focus in the primary transformation unit.}

- How can I as an educator help a child with difficulties? Can you get a profile on how the child learns best? Advice on what instructions you can give the child, how best to help the child. Why do the kids get stuck when they get stuck? Suggestions on what to do physically to practice this. How can the child get over the threshold? Can you visually see what happened to the child over time during the semester?

- If you get notifications, you can get your eyes on what a child needs to practice. There should be a visual presentation of the child's development. Two versions: one for the educator and one for guardians/children. Something one can show at parental meetings.

- How can you make sure that educators don't just "tick off" math without getting involved, since the game is self-instructive?

At this point of the LDS the educators seem to be imagining using the tool in their teaching, with different suggestions on how it should, and should not, be used-as illustrated in Excerpt 6.6. During the WS they explore how it could be used to target specific children (and also how it can be used when in contact with guardians). The educators begin to be critical of their own creations and to discuss possible negative effects.

\section{WS3 secondary transformation unit}

Several themes were initiated in the secondary transformation unit. In WS3 part of the educator's tool was discussed where the educators could create and make their own mathematical content. This was not initiated in the two earlier WSs, nor followed up in the last two. Two more tracks were suggested here: one for the most advanced learners, and one for children who are less advanced learners. This was not discussed previously, nor was it followed up. In the educator's tool it could be possible to access this kind of information about a child since children's mathematical advancements are logged-yet, preschool is not about ranking children so there will be no such function. In the final large group discussion, the educators highlighted that the analogue and the digital must go hand in hand; they also suggested the use of a tab for physical mathematics. 
Some examples of results from WS3 implemented in the prototype are:

- visual representations of children's progress, learning, and struggles in early mathematics;

- links from a child's level in Magical Garden to the educator's tool where suitable physical mathematics games at the same level are presented;

- the opportunity for the educator to choose the path through Magical Garden and to all the different levels;

- the need for a more mature/professional address, such as font size \& type and layout, in the educator's tool than in the game.

\section{WS3 analysis of the primary and secondary transformation unit}

The discussion in the primary transformation unit was led by the masters student who had not been a central part of the WS series before. There is a chance that this challenged the institutional norms we had built up, because many new suggestions were raised, including inviting guardians to become familiar with the educator's tool to take part in monitoring the child's progress and learning (and possible difficulties) in mathematics. This is not aligned with the preschool mission and curriculum and so would never be designed into the tool. WS3 was the first WS where we intended to initiate the setting before the LDS, and the WS was thus preceded by the "homework" (as mentioned above). This kind of didactic design did not work well, since the educators did not find time to engage in it beforehand as intended, and accordingly this didactic design was not used again.

\section{WS4-empirical example}

All events in WS4 (2020-04-02; 2020-05-03; 2020-06-01; and 2020-06-03) can be placed in the LDS model's primary transformation unit where educators are in a formative process.

\section{WS4 setting}

In the fourth WS the most prominent resource was the educator's tool and, since this took place during the pandemic crisis, Zoom was used. The institutional norms were challenged again since we were used to meeting physically in a room, but now had to design the WS differently. The WS was planned to be in person, but was first cancelled, then postponed, and in the end held via Zoom. The WS was designed as a prototype testing session where the research group members played the game Magical Garden to create several different game logs at different levels. The educator's tool could thus be tested when the educators used the visualized logs to intervene in learning to support mathematical learning. Unfortunately, only one educator came to this WS via Zoom, so we added two more workshops 
held by the stakeholders (the two project members who are also working as preschool teachers) in their respective preschools with their colleagues. Many ethical discussions took place in the project group concerning the ethical correctness of inviting preschool teachers to digital workshops while they were in the middle of the pandemic crisis. After postponing the WS a few times, we sent out an invitation, but were keen to make clear that participants would not feel forced to join us: "The workshop is optional so just say yes if you feel you have time to spend a few hours on preparation the week before the workshop. We know that you are struggling with all the anxiety and extra work that these new times mean, so we do not want to burden you any further."

\section{WS4 primary transformation unit}

The WS outline, as presented at the beginning of the WS, was divided into five parts:

1 Three introduction videos were displayed.

2 The follow-up tool was set up for exploration.

3 The website was improved and set up for review.

4 A special tab on the website called "Preschool mathematics" and the heading "Why is preschool mathematics so important?" was made the basis for discussion.

5 Independent explorative work with the material was carried out.

Examples of questions asked by the educators about the educator's tool and the follow-up tool include:

\section{Excerpt 6.7 The educators' questions about the different parts of the educator's tool.}

\section{The educator's tool}

Is it easy to understand? Is something missing? Is something superfluous/unnecessary? Should it be presented in some other way? Should the language itself be changed? Is more help/support needed to download (and then print)? Can you think of a better heading than "Game in the Room"?

\section{The follow-up support}

Do you understand everything? How should we proceed? 
Excerpt 6.7 illustrates the WS leader's questions, prompting a metareflective discussion between the educators about the educator's tool. One part of the tool was the new "Follow-up support," which the educators seemed thrilled about.

\section{WS4 secondary transformation unit}

The educators at the preschools discussed three highlights from the educator's tool:

1 Instructional films: They liked the mode $\&$ media of a multimodal film and they appreciated the content as it is considered important to be aware of mathematics and to pronounce and highlight the mathematical terms.

2 The site: They liked the site with the suggestions on physical mathematical games in the extended digital interface (Kjällander, 2011) and the suggestions to bring Magical Garden out into the physical room, so called extensions (Gulz et al., 2020a), but did not see the difference between the two.

3 The follow-up tool: The tool was hard to use for intervening in children's learning, but the details in which the children's information could be visualized were appreciated.

The following are examples of findings from WS4 implemented in the prototype:

- There is a need for printable material.

- There must be better evaluated and grounded use of colours in the tool.

- There need not necessarily be a visible actor in the film clips.

- The connection between the different parts of the different tabs in the tool must be visualized.

- The widespread misconception that preschool mathematics is only a preparation for school must not be promoted.

- Examples of extensions from the digital into the physical should be illustrated.

- Connections between the follow-up tool and the suggested games must be more clear.

\section{WS4 analysis of the primary and secondary transformation unit}

The Covid-19 pandemic challenged the project, and the research group felt it was ethically questionable to invite educators to participate in the WS when they were struggling with absent colleagues and worries about personnel, children, and parents. Our stakeholders let us know that life in preschool went on just as normal, but we decided not to arrange a WS requiring physical attendance. We do not know whether the educators did not attend the WS4 because of the factors listed above, or whether it was just because they did not want to attend a WS via Zoom. We think it was probably the latter since they were positive about an alternative, a face-to-face WS with the stakeholders. 


\section{WS5-empirical example}

WS5 (2020-09-14) can be placed in the LDS model's secondary transformation unit where the representation is a focal point along with metareflective discussions and assessment.

\section{WS5 setting}

Once again, the institutional norms and curricular matters were changed, since the pandemic circumstance at this time meant that we could now meet, but keeping at all times a two-meter physical distance. The two stakeholders made sure there would only be a few participants in the room, with the rest on Zoom, and we had a large table where we could all keep a suitable distance apart. The learning resources were therefore Zoom, some computers and tablets, and a large TV screen on which the educator's tool was displayed. The aim of this last WS was thus two-fold: to conduct a last-minute-review of the tool, and to "give something back" to the WS participants-namely, to pre-release the tool to them.

\section{WS5 primary transformation unit}

This workshop was not as strictly designed as the others, since the educator's tool was almost complete, and would be presented and debugged for final alterations before the pilot study the week after. WS5 had three parts, of which two are in the first transformation unit: (1) the presentation of the almost finalized educator's tool, and (2) the time for participants to try the tool on their own iPads (i.e., group children, watch the videos, try the mathematics games). Some of the participants had viewed and tried out the educator's tool beforehand, but we presented it carefully to all at the beginning. They tried the educator's tool on their own iPads before engaging in a workshop with the following questions to structure their discussions:

\section{Excerpt 6.8 Questions asked by the researchers to intervene in the educators' discussion of the educator's tool.}

Is it easy and understandable to navigate the follow-up support?

Is there any information/data you would like to get more of in the follow-up support?

Is it clear enough if a child has problems and what the problems might be?

How would you use the information about an individual child, or for a group of children, to do activities outside the game? 
The discussions in this WS were clearly based on the educators' professions. The questions from the WS leader, as illustrated in Excerpt 6.8, afforded them the possibility to imagine using the tool with specific children in their preschool group.

During this WS's Body \& Mind activities, Brain Train (Neville et al., 2013) was finally incorporated into the educator's tool, after being introduced at the beginning of the WS series and discussed from time to time during the workshops. The package's position was discussed and the following was decided: There must be a clear idea on how, when, and how often the activities should be carried out. The connection between early mathematics and Body \& Mind must be clear.

\section{WS5 secondary transformation unit}

The third and final part of WS5 was: (3) the discussion, with participants in the room and via Zoom. As the tool was almost ready for piloting, the discussion was focused on headings, button design, chronological order, and symbols (which could all be updated before the pilot). Crucially, it was also necessary to pay attention to the children's many spoken languages, and to the children's different mental and physical functional variations, in the production of the tool. Examples of findings from WS5 implemented in the prototype are:

- Some diagrams had the wrong order of "history" buttons.

- The list needed to be reversed-with newer on top and older at the bottom.

- Change the name of the tab "Hints \& games" to a more professional heading, for example, use a title such as "teacher guide," "support," or "handbook."

\section{WS5 analysis of the primary and secondary transformation unit}

The importance of choosing the right notions to legitimate preschool educators' professionalism was prominent in this WS. This was invoked in earlier WSs, but the reason for this standpoint was not explained. WS5 presented an ethical dilemma and we questioned ourselves on what was worse: meeting physically but at a distance yet still risking infection; or failing to give back some competence, information, and/or in-service-training. We communicated with the operations manager, head teachers, educators, the university, and The Public Health Agency of Sweden (www.folkhalsomyndigheten. se/the-public-health-agency-of-sweden/). Based on their joint request we decided that, since we had already promised in the first information letters about the project that they would be the first to see results and products, we wanted to have the final WS as a physical meeting in a room, rather than a virtual WS. By the end of the primary transformation unit, the educators no longer described their participation in the workshop series as only "helping the researchers." Rather, they appreciated their participation as in-service training for their own professional learning, and their discussions and metareflections 
were highlighted as valuable representations for their own benefit as well as for that of the researchers.

\section{Concluding discussion}

This chapter has cast light on workshops as a multimodal research method (Kress, 2010; Selander, 2008; van Leeuwen, 2005)—an area that, according to Orngreen \& Levinsen (2017), is not so common in research within this theoretical field. It contributes to knowledge on how a workshop series with interdisciplinary researchers and educators with different educational backgrounds (i.e., caregivers, preschool teachers, and head teachers) can be used to design a digital, multimodal tool for education. Compared to earlier research it can be concluded that the DigiTaktik workshop series has many common features with many research workshops (Ørngreen \& Levinsen, 2017) in that we had arranged events with participants who work in the same field.

The WSs were conducted by researchers and experienced educators, and even if we expected an outcome in the form of a tool, this tool was indeed built on new insights, innovation, and suggestions by the participants. We designed for a small participant group where everyone could be active and could be heard, in order to promote genuine participation and social interaction, and to allow personal attention. We also continuously practiced the relevant techniques, skills, and situations while designing the tool. Individualization and feedback, highlighted as the most crucial in a WS, according to Ciampa (2016), went both ways in the WS series. I would argue that the DigiTaktik WS could be understood as a "Technology Professional Development Workshop," as expressed by Ciampa (2016). The workshop series represents a longitudinal workshop series of over almost two years. Orngreen and Levinsen (2017) stated that no studies in their literature review discussed how workshops could be used as a method for enlightening a domain over long periods of time.

This chapter has presented an account of how the model LDS was used as a design and analysis resource with the aim of developing a functional educator's tool to help preschool educators to intervene in children's learning. During the first WS, the institutional norms of the setting in the LDS were appreciated by the teachers as though the aim was to help and support research. During the WS series, this was transformed and they began to form a new aim- to acknowledge their own signs of learning during the period of time. By the time of the final WS, it was obvious that they appreciated the WS series as in-service-training for themselves. In the first workshop educators were already aware of new knowledge, and their utterances often vividly illustrated that they developed their professional learning by means of signs of learning in the interaction with the researchers - and vice versa.

It is complex to ask didactic questions in an environment of distributed resources where the textbook is no longer in use, but there are instead a vast 
number of digital resources (Selander, 2017). Selander highlights the relations between the goal, curriculum, resources, and the teacher/student, when a concrete artefact such as an educator's tool is being formed in social interaction. The importance of a having common language in the workshop series was highlighted. The common language developed in social interaction, using the same words in the educator's tool as in the preschool curriculum in order to support and dignify the use of the tool. Even if educators began using theoretical notions, the largest language transformation was made by the researchers who realized how much the educators knew and valued their curricular texts and concepts.

During the two years, educators asked for (and then sometimes dismissed) the possibility of having summative assessment with notifications to their emails, and the possibility of displaying an individual child's mathematical processes to both children and guardians. This kind of summative assessment of individual children was not supported by the preschool national curriculum and was therefore not built into the tool. Both researchers and educators experienced a transformed and formed representation of knowledge. For the research team, Signs of learning were that the educators, even if they really wanted to, did not have time to read or prepare between the workshops.

It was obvious that the educators kept the project in mind in between the WSs and had discussed their thoughts since they presented elaborated reasoning that made connections between the different WSs. We learned that they were extremely effective, engaged, and productive during the three hour WSs, and came to appreciate every single moment together. Also, it turned out to be very fruitful to "give back" to the participant during each WS, with food and engaging informative discussions and, on some occasions, a bit more with lectures, free books, and invitations to exciting events. We created good relationships that hopefully will last, and we know the participants valued this since they participated over and over again (except during the pandemic), regardless of the immense workload they were experiencing in preschool.

The researchers had limited experience about this kind of formative assessment and participated reluctantly, but the educators were eager to have children's design in learning visualized and displayed. In preschool, educators have limited time for planning. Researchers are well aware of this, and designed the tool accordingly, with short films and text, for example, implemented in every tab of the educator's tool. All films, texts, and other instructions or information are brief, with a maximum of five minutes to watch a video, learn a game, or prepare for an exercise. Everything is illustrative and multimodal with images, moving images, sounds, voice, symbols, colours, and diagrams, with the aim that even a quick glance should make sense to the educator. We hold that the LDS model could be used to plan, design, and implement workshops as a research method, and we believe that the tool that we designed and built together can be used in preschool. 


\section{Final remarks on the methodology}

The design and the implementation and the analysis of a workshop series as a research methodology making use of the Learning Design Sequence worked out well. The different transformation units and their notions helped us to analyze one WS, transform and update the tool, and prepare for the next WS. Initially, during the research application process, we were more focused on designing, what Ørngreen and Levinsen (2017) would call "Workshops as research methodology" to inform our own design of the educator's tool. During the process our pre-understanding was transformed and we became increasingly involved with the WS participants, with the result that the design of the WS series transformed more into the category of "Workshops as a means," as we actually built the tool and learned together. The didactic design during the WS series transformed depending on the transformation unit of the whole two-year LDS in which the specific WS was situated. In the first workshops we designed an open environment with social interaction and brainstorming where everything was possible - it did not have to be realistic at that point. In the following WS the didactic design implied representation and production, therefore many creative but unrealistic suggestions were assessed and dismissed. Instead, the educators strove to build the tool with a professional language that was common and familiar, and closely connected to the curriculum; a tool that can be trusted by the educators when learning is distributed (Selander, 2017). I would like to finish with a quote from Ørngreen and Levinsen (2017):

The workshop co-constructs a place for collaborative negotiation of meaningnot only between participants, but also between facilitators (the researchers) and participants, who both during and after the workshop adopt and adapt to what is being discussed, performed, and learned. Through this, workshops bring us close to practice without being in practice.

\section{Acknowledgements}

I would like to thank all educators who have participated in the workshop series, Magnus Haake who designed the workshop series, and the Swedish Institute of Educational Research for funding this research. I also want to thank Frankenberg, Gulz, Haake, Pakulak, Yildirimdemir, Ring, Hagås and Koniakowski.

\section{Notes}

1 Developed by Educational Technology Group, Lund University.

2 Cognitive Science, Lund University

3 Didactic Science and Developmental Psychology, Stockholm University 
4 For a more conclusive presentation of modality and coding orientation, see Kress and van Leeuwen (2006).

\section{References}

Biswas, G., Katzlberger, T., Bransford, J., Schwartz, D. L., \& TAG-V. (2001). Extending intelligent learning environments with teachable agents to enhance learning. In J. D. Moore, C. L. Redfield, \& W. L. Johnson (Eds.), Artificial intelligence in education (pp. 389397). IOS Press.

Calkins, L., \& Tolan, K. (2010). A guide to the reading workshop. FirstHand \& Heinemann.

Ciampa, K. (2016). Implementing a digital reading and writing workshop model for content literacy instruction in an urban elementary $(\mathrm{K}-8)$ school. The Reading Teacher, 70(3), 295-306.

Gibson, J. J. (1979). The ecological approach to visual perception. Houghton Mifflin.

Gulz, A., Kjällander, S., Frankenberg, S., \& Haake, M. (2020a). Early math in a preschool context: Spontaneous extension of the digital into the physical. IxDEA: Interaction Design $\mathcal{E}$ Architecture, (44), 129-154.

Gulz, A., Londos, L., \& Haake, M. (2020b). Preschoolers' understanding of a teachable agentbased game in early mathematics as reflected in their gaze behaviors-an experimental study. International Journal of Artificial Intelligence in Education, 30(1), 38-73.

Husain, L., Gulz, A., \& Haake, M. (2015). Supporting early math-rationales and requirements for high quality software. Journal of Computers in Mathematics and Science Teaching, 34(4), 409-429.

Kjällander, S. (2011). Designs for learning in an extended digital environment. Case studies of social interaction in the social science classroom. Diss.

Kjällander, S. (2019). Övergripande aspekter av digitalisering i förskolan. In S. Kjällander, \& B. Riddersporre (Eds.), Digitalisering i en förskola på vetenskaplig grund (pp. 21-40). Natur \& Kultur.

Kress, G. (2010). Multimodality: A social semiotic approach to contemporary communication. Routledge.

Kress, G., Jewitt, C., Ogborn, J., \& Tsatsarelis, C. (2001). Multimodal teaching and learning the rhetorics of the science classroom. Continuum.

Kress, G., \& van Leeuwen, T. (2001). Multimodal discourse: The modes and media of contemporary communication. Arnold.

Moreno-Ger, P., Burgos, D., Martínez-Ortiz, I., Sierra, J. L., \& Fernándes-Manjón, B. (2008). Educational game design for online education. Computers in Human Behaviour, 24(6), 2530-2540.

National Agency for Education. (2018). Curriculum for the preschool, Lpfö 18. Skolverket. www. skolverket.se/publikationsserier/styrdokument/2019/curriculum-for-the-preschoollpfo-18

Neville, H., Stevens, C., Pakulak, E., Bell, T. A., Fanning, J., Klein, S., \& Isbell, E. (2013). Family-based training program improves brain function, cognition and behavior in lower socioeconomic status preschoolers. In PNAS. Early Edition.

Newfield, D. (2014). Transformation, transduction and the transmodal moment. In C. E. Jewitt (Ed.), The Routledge handbook of multimodal analysis (pp. 100-113). Routledge.

Ørngreen, R., \& Levinsen, K. (2017). Workshops as a research methodology. Electronic Journal of E-Learning, 15(1), 70-81. 
The Public Health Agency of Sweden. www.folkhalsomyndigheten.se/the-public-healthagency-of-sweden/

Selander, S. (2008). Designs for learning: A theoretical perspective. Designs for Learning, 1(1), 4-22.

Selander, S. (2009). Didaktisk Design [Didactic design]. In S. Selander \& E. Svärdemo-Åber (Eds.), Didaktisk design i digital miljö—nya möjligheter för lärande [Didactic design in digital environments: New opportunities for learning]. Liber.

Selander, S. (2017). Didaktiken efter Vygotskij—design för lärande [Post-Vygotskian education: Designs for learning]. Liber.

Selander, S., \& Kress, G. (2017). Design för lärande-ett multimodalt perspektiv [Designs for learning: A multimodal perspective] (2nd ed.). Studentlitteratur.

van Leeuwen, T. (2005). Introducing social semiotics. Routledge. 